翻訳—メッセンジャーRNAから タンパク質ヘー

\section{1. セントラルドグマ}

本連載の第 2 回で, タンパク質とはどのようなもので あるか、またとの多種多様な役割が微生物から私達のよ らなヒトの生存にとってどんなに大切であるかを括し ました。でも，生物が生きて行くためにはこのように 複雑なタンパク質を必要な時に, 必要な所で, 必要な量 だけ作り出さなければなりません。今回は,タンパク質 分子が細胞内で生合成される仕組みについて述べること にします。

核のなかの DNA の遺厷子情報の発現の仕組みは, 1958 年クリックによって晿光られ，セントラルドグマ （一般原理）と呼ばれています。すなわち，DNAの 2 本 鎖の一部が巻き戻されて 1 本鎖になり, 片方の鎖が鋳型 となって DNA の遗伝情報が相補的な塩基配列として RNA 鎖に写しか兄られ， mRNA が合成されます（転 写)。DNA のコピーである mRNA は核から細胞質に 移動し、リボソーム上で mRNA の遺伝暗号が読みとら れ, 特定のアミノ酸が一定の順序に結合されタンパク質 が合成されます。この過程を翻訳といいます。これは, 動物, 植物, 微生物によって変水らない生命現象の基本 的原理です。

\section{2.リボソーム, トランスファ RNA}

翻訳にはいろいろな成分が関与します。最も重要なの は, 細胞中の全 RNA の数\%しかない mRNA です。 mRNA は DNA の遺伝情報をタンパク質合成の主役で あるリボソームに伝觉るのがその役割です。リボソーム はリボヌクレオタンパク質からなる大きな粒子（70 S) で，翻訳が行われる場所です。リボソームはすべて大小 二つのサブニニットからなり, 原核細胞の場合小さい方 が $30 \mathrm{~S}$ ，大きい方が $50 \mathrm{~S}$ の大きさです。 $30 \mathrm{~S}$ リボソー ムサブニニットは $16 \mathrm{~S}$ RNA と 21 個のタンパク質, $50 \mathrm{~S}$ サブュニットは $23 \mathrm{~S}$ RNA，5S RNA と 34 個の タンパク質から構成されています。これら多くのタンパ ク質は,すべて翻訳の過程で必要な機能や構造を維持す るのに働いています。

トランスファーRNA(tRNA)は, 翻訳の際に活性化さ れた各種のアミノ酸と特異的に結合し、アミノ酸を運ぶ 役割をもつ RNA です。このアミノ酸と結合した tRNA (アミノアシル-tRNA) は, リボソーム上で mRNA の 遗伝暗号（コドン）を対応する 3 塩基（アンチコドン） が特異的に mRNA の 3 塩基に結合することにより読 みとり, mRNA の遺伝情報をタンパク質合成のアミ， 酸の配列に反映させせす。タンパク質に普通に存在する 20 種のアミノ酸に対応して, 約 40 種の tRNA があ ります。構造が解明された tRNA は 75〜87 個のヌクレ オチドからなり，そのらち 10〜20\% は修飾されたヌク レオチドです。3' 末端はすべて C-C-A といら配列にな っています。

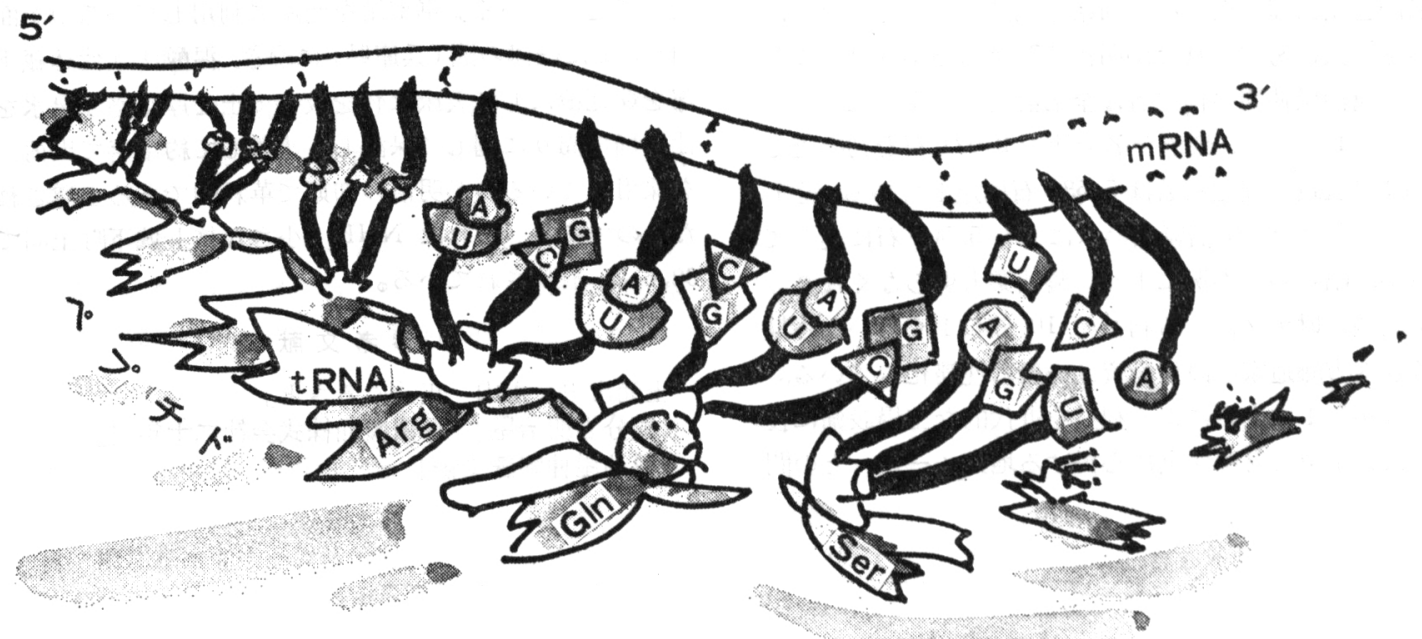

mRNA からタンパク質へ——翻訳のしくみ 
コドンは, mRNA 上の三つの隣接するリボヌクレ オチドからなる遺伝情報の暗号の単位で, 64 種ありま す。61 種のコドンは各々アミノ酸一つを指定していま す。たとえば, セリン，ロイシン，アルギニンには 6 種 のコドンが存在し, トリプトファンのコドンは 1 種で す。また， 3 種はどのアミノ酸も指定しないナンセンス コドンといわれ，遺伝情報の読み終りの暗号（終止コト゚ ン) です。

3. ペプチド鎖合成の開始, 伸長, 終止 翻訳の過程は大きく分けて 4 段階からなっています。 すなわち，1）アミノ酸の活性化，2）ペプチド鎖合成の 開始，3）伸長，4）終止です。まず 20 種のアミノ酸 は,すぺてそれぞれに特異的な活性化酵素（アミノアシ ル-tRNA シンテターゼ) により活性化され，活性化さ れたアミノアシル基は特異的な tRNA に結合します。

つぎにポリペプチド鎖の合成が始まるには, $30 \mathrm{~S}$ のリ ボソームサブュニット， mRNA， 3 種のタンパク質 $\mathrm{F}$ 1, F 2, F 3 からなる開始複合体ができます。この複合 体は GTP と $\mathrm{Mg}^{2+}$ があると, 特別な開始 tRNA であ るN-ホルミルメチオニル-tRNAを mRNA の開始コト ン AUG のところに結合します。なた゚し、これは原核 細胞の場合であり，真核細胞ではメチオニル-tRNA が 開始 tRNA となります。こうして $30 \mathrm{~S}$ サブュニット，
mRNA， N-ホルミルメチオニル-tRNA，F 1，F 2，F 3 の複合体ができると、これに $50 \mathrm{~S}$ サブニニットが付き， F 1, F 2 が離れて $70 \mathrm{~S}$ のリボソームとなり完全な合成 開始複合体になります。

ペプチド鎖の伸長は, リボソームの部位 $\mathrm{A}$ (アミノア シル部位) ヘのアミノアシル-tRNA の結合, 部位 $\mathrm{P}$ (ペ プチジル部位) に結合しているペプチジル-tRNA から 新たに部位 $\mathrm{A} に$ 付いたアミノアシルーtRNA のアミノ基 へのペプチジル基の転移，そして mRNA が1コドン

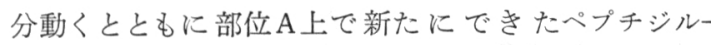
tRNA か゚部位 Pへ移行するといらサイクルを繰り返すこ とにより進行します。これには三つのタンパク質因子 Tu, Ts, G および $50 \mathrm{~S}$ サブュニットのペプチジルト ランスフェラーゼ作用が必要です。

最後にペプチド鎖の合成は mRNAの終止コドン UAA，UAG，UGA を識別し，完成したポリペプチドと tRNA のエステル結合を加水分解して終止します。この 過程には R 1 または R 2, S, TR といらタンパク質因 子が関与します。このようにして合成されたタンパク質 は, $\mathrm{N}$ 末端の $\mathrm{N}-$ ホルミルメチオニンの除去, シグナル ペプチドの切断, 翻訳後の修飾などを経て, 成熟タンパ ク質となるのです。

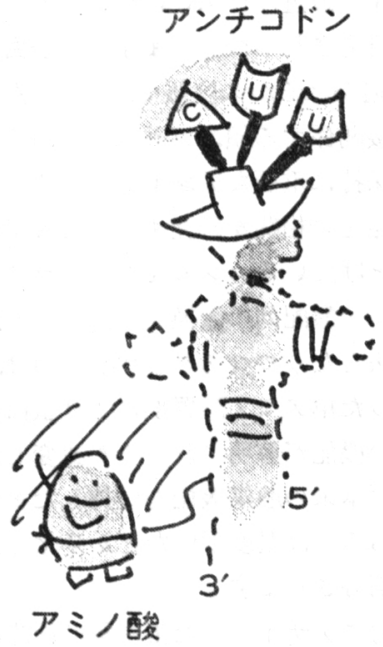

(グルタミン酸)

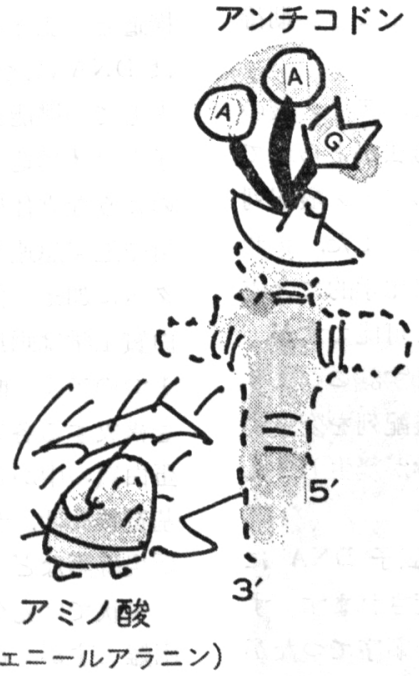

(フェニールアラニン)

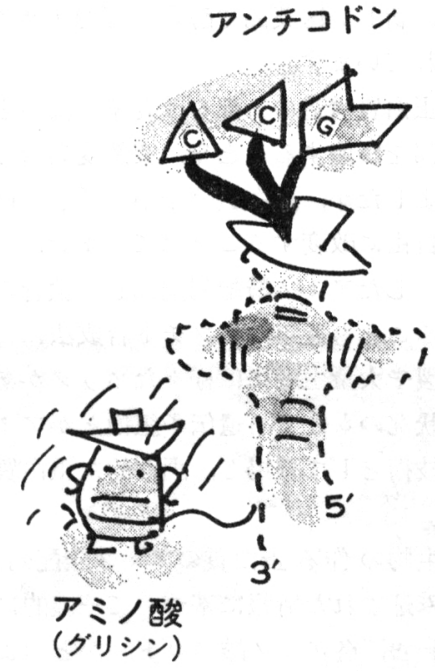

(グリンン)

tRNA の働き…...

帽子の飾りによって運ぶアミノ酸が決まる

文三上重明

克さとうひろし 